\title{
EFFECT OF SELECTED HEAVY METAL IONS ON THE GROWTH OF ENTOMOPATHOGENIC FUNGI FROM THE GENUS ISARIA
}

\author{
TKACZUK, C..$^{*}$ - MAJChrowska-SAFARYAN, A. ${ }^{1}$ - PANASIUK, T. ${ }^{1}-$ TIPPING, C. $^{2}$ \\ ${ }^{I}$ Department of Plant Protection and Breeding, Faculty of Natural Science, Siedlce University \\ of Natural Science and Humanities, B. Prusa 14, 08-110 Siedlce, Poland \\ ${ }^{2}$ Department of Plant Science, Delaware Valley University \\ 700 East Butler Avenue, Doylestown, PA 18901, USA \\ *Corresponding author \\ e-mail: cezary.tkaczuk@uph.edu.pl \\ (Received 12 $2^{\text {th }}$ Nov 2018; accepted 25 ${ }^{\text {th }}$ Jan 2019)
}

\begin{abstract}
This paper examines the effects of selected heavy metals: zinc, nickel, copper, cadmium and lead, on the growth of three species of entomopathogenic fungi of the genus Isaria Pers.: I. farinosa (Holmsk.), I. fumosorosea Wize, and I. tenuipes Peck. Ions of metals were added to the Sabouraud medium in three concentrations: $1 \times-$ concentration corresponding to the natural content of the given metal in Polish soils; $10 \times$ - concentration 10 times higher, and 100× - concentration 100 times higher than the natural content. Heavy metal ions in concentration $1 \times$ did not significantly restrict the growth of fungus colonies, and in some cases caused a slight growth stimulation. The greatest toxic effect of heavy metal ions on the entomopathogenic fungi was observed when their concentration was 100 times higher than the natural content. Nickel had the greatest inhibitory effect on the growth of fungal colonies, while lead showed the least effects. The fungal species most sensitive to the presence of heavy metals in the medium was I. tenuipes, while I. fumosorosea had the highest tolerance.
\end{abstract}

Keywords: insect-pathogenic fungi, metal-resistance, mycelial growth, Hypocreales, soil

\section{Introduction}

Heavy metals are considered one of the most dangerous environmental pollutants created as a result of human economic activities, both agricultural and non-agricultural (Kabata-Pendias and Pendias, 2001; Goyer, 2001; On et al., 2005; Micó et al., 2006). In the soil they react with other chemicals, accumulating in different forms with differentiated bioavailability to plants (Singh and Kalamdhad, 2011).

The solubility of heavy metals in soil, and hence their biological effects, decreases with increasing content of organic matter or clay minerals, and increases under higher acidity (Kabata-Pendias and Pendias, 1999, 2001). Metals in natural concentrations are often essential in the functioning of living organisms, but often have toxic effects when present in excessive amounts (Badura and Piotrowska-Seget, 2000; Singh and Kalamdhad, 2011). Additionally, their presence in soil has a major impact on cellular structures, growth and development, and biological activity of soil microorganisms (Badura and Piotrowska-Seget, 2000; Tscherko et al., 2007; Hassn et al., 2014).

Although heavy metals naturally occur in the soil environment, presently there are many factors significantly contributing to their increase such as industrial activities, and perhaps most importantly, the intensification of agricultural production using chemicaldependent farming methods (Lenart and Wolny-Koładka, 2013). The European Parliament and Council Regulation (EC) No 1107/2009, states the use of integrated plant protection natural alternatives should be considered a priority instead of the use of chemical ones (Tomalak, 2010). The use of products with biological origin based on 
micro-organisms such as entomopathogenic fungi are becoming increasingly important (Sheeba et al., 2001; Meyling and Eilenberg, 2007; Tkaczuk, 2008; Batta et al., 2011; Schemmer et al., 2016; Showket et al., 2017).

Entomopathogenic fungi are a very important component of the environment and infect many species of arthropods causing disruption of physiological processes in the host followed by mortality (Hajek and Leger, 1994; Chandler et al., 2000; QuesadaMoraga et al., 2007). They occur primarily in the soil and constitute an essential part of the organic biomass (Ferron, 1981; Keller and Zimmermann, 1989; Tkaczuk, 2008). Soil often provides the substrate for the maintenance of a natural reservoir of many entomopathogenic fungi. Soils can be inoculated with these fungi either by an infected insect entering the soil or by the deposition of spores on the soil surface by natural dispersion mechanisms (Hajek, 1997). Presence and pathogenicity of many entomopathogenic fungi depend on interactions with host organisms, prevailing climatic conditions, and other biotic and abiotic factors.

Laboratory studies have shown that heavy metals impact the growth, metabolism, and pathogenicity of entomopathogenic fungi (Ropek and Para, 2003; Baldrian, 2003; Pečiulytė and Dirginčiutè-Volodkienè, 2012; Hassn et al., 2014). Ecotypes of specific species of entomopathogenic fungi accumulate heavy metals in different amounts leading to diverse effects on growth and pathogenicity (Popowska-Nowak et al., 2004; Tkaczuk, 2008).

Some of the hypocralean fungi most commonly found in the soil environment that are highly parasitic to insects include species of the Isaria Pers. genus (Zimmermann, 2008; Ropek et al., 2014). Isaria farinosa (Holmsk.) is frequently responsible for natural epizootics among butterflies overwintering as pupa especially in soil and forest litter (Vänninen, 1996; Chandler et al., 1997). Isaria fumosorosea Wize is used to produce a bio-insecticide to control whiteflies infesting greenhouse production plants (Gonzales et al., 2016). Isaria tenuipes Peck. causes epizootics of larval and pupal stages of several lepidopterous pests. After the death of the host, the fungi produces fascicles of hyphae, referred to as synnemata, which emerge from the cadaver and produce great amounts of conidia (Fukatsu et al., 1997).

The purpose of this paper is to investigate the effect of selected heavy metal ions on the growth of entomopathogenic fungi of the Isaria genus under laboratory conditions.

\section{Materials and methods}

\section{Fungal isolates}

Laboratory tests examined the effects of five selected heavy metal ions: zinc, nickel, copper, lead, and cadmium, on the growth of Isaria farinosa, I. fumosorosea, and $I$. tenuipes. The fungal material was obtained from stock collections maintained at the Department of Plant Protection and Breeding, Siedlce University of Natural Sciences and Humanities, Siedlce, Poland.

Initial isolates of I. farinosa and I. tenuipes were obtained from infected pupae of an unidentified butterfly species found in leaf litter of mixed woods in the vicinity of Siedlce. The isolate of I. fumosorosea was obtained from the soil of cultivated fields and collected using the 'insect bait' method.

The fungi were identified on the basis of morphological characteristics, using identification keys (Inglis et al., 2012; Humber, 2012). Prior to treatments, isolates were 
applied to Petri-plates with Sabouraud medium and maintained at $20 \pm 2{ }^{\circ} \mathrm{C}$ for 7 days in total darkness.

\section{Preparation of media with metal ions}

Heavy metal ions were added to sterile Sabouraud medium in three concentrations: $1 \times$ - concentration corresponding to the mean content of that metal in Polish soils, $10 \times-$ concentration 10 times higher and $100 \times-100$ times higher than the natural content. Treatment concentrations are listed in Table 1. Metal ions were added to the culture media in the form of various salts.

Table 1. Characteristics of heavy metal salts used in the experiment

\begin{tabular}{c|c|c}
\hline Ion & Salt used & $\begin{array}{c}\text { Concentration of ion corresponding to the natural content in soil } \\
(\mathbf{m g} / \mathbf{l})\end{array}$ \\
\hline $\mathrm{Cu}$ & $\mathrm{CuSO}_{4} \times 5 \mathrm{H}_{2} \mathrm{O}$ & 6.5 \\
$\mathrm{Zn}$ & $\mathrm{ZnSO}_{4} \times 7 \mathrm{H}_{2} \mathrm{O}$ & 33.0 \\
$\mathrm{Ni}$ & $\mathrm{Cl}_{2} \mathrm{Ni}_{6} \times 6 \mathrm{H}_{2} \mathrm{O}$ & 6.5 \\
$\mathrm{~Pb}$ & $\mathrm{~Pb}\left(\mathrm{NO}_{3}\right)_{2}$ & 13.8 \\
$\mathrm{Cd}$ & $\mathrm{CdCl}_{2} \times 2 \mathrm{H}_{2} \mathrm{O}$ & 0.22 \\
\hline
\end{tabular}

The Sabouraud medium was treated with $\mathrm{H}_{2} \mathrm{PO}_{4}{ }^{-}$and $\mathrm{HPO}_{4}{ }^{2-}$ as a buffer to maintain $\mathrm{pH}$ of 6.4. Plates were centrally inoculated with a mycelial disc of 3-4 $\mathrm{mm}$ in diameter, and were stored in darkness at $20^{\circ} \mathrm{C}$. The colony diameter was measured 5, 10, 15 and 20 days after inoculation. Each experimental combination and the control with no metals were replicated four times. All laboratory experiments were achieved at the Siedlce University of Natural Sciences, Department of Plant Protection and Breeding, Siedlce, Poland in 2017.

\section{Statistical analysis}

Size of fungus colonies, expressed as a percentage in relation to the control, were treated as variables. The results were processed statistically using the Statistica 12 program. Tukey's test and single-factor analysis of variance at a significance level of $\alpha=0.05$ were used to compare group means.

\section{Results}

Metal ions of zinc, nickel, copper, lead, and cadmium affected the growth of Isaria genus in various ways, with the reaction dependent on the type of metal as well as concentration. Levels of zinc, copper, and cadmium at the levels found in native Polish soils caused a slight stimulation of colonies of Isaria farinosa (Table 2).

After 20 days all colonies I. farinosa on the media with $1 \times, 10 \times$, and $100 \times$ heavy metal concentrations grew, respectively, $110.8 \%, 115.8 \%$, and $102.8 \%$ of the control colony diameter. Twenty days after the application of ionic cadmium and lead with the concentration 10 times higher than the natural content $(10 \times)$ that the diameter of the $I$. farinosa colony was $32.9 \%$ smaller than the control for cadmium and $30 \%$ smaller for lead. Other heavy metals added to the media at $10 \times$ concentration did not significantly affect the growth of the colonies. Of all the heavy metals cadmium and nickel ions at 
the concentration 100 times higher than natural the most strongly inhibited the growth of the $I$. farinosa cultures.

Table 2. The size of colonies of the fungus Isaria farinosa on medium in the presence of heavy metals ions (expressed in \% of control)

\begin{tabular}{|c|c|c|c|c|c|}
\hline \multirow{2}{*}{ Metal } & \multirow{2}{*}{$\operatorname{Con}^{1}$} & \multicolumn{4}{|c|}{ Date of observation in days } \\
\hline & & 5 & 10 & 15 & 20 \\
\hline \multirow{3}{*}{$\mathrm{Zn}$} & $1 \times$ & $103.7 \pm 0.2 \mathrm{~b}$ & $103.7 \pm 0.8 \mathrm{a}$ & $119.8 \pm 0.1 \mathrm{~b}$ & $110.8 \pm 0.0 \mathrm{c}$ \\
\hline & $10 \times$ & $106.9 \pm 0.4 \mathrm{~b}$ & $91.7 \pm 2.1 \mathrm{a}$ & $111.6 \pm 0.8 \mathrm{~b}$ & $96.7 \pm 0.0 \mathrm{a}$ \\
\hline & $100 \times$ & $93.1 \pm 0.3 \mathrm{a}$ & $88.6 \pm 0.8 \mathrm{a}$ & $103.0 \pm 0.1 \mathrm{a}$ & $100.5 \pm 0.0 \mathrm{~b}$ \\
\hline \multicolumn{2}{|c|}{ Control } & $100 \mathrm{ab}$ & $100 \mathrm{a}$ & $100 \mathrm{a}$ & $100 \mathrm{~b}$ \\
\hline \multirow{3}{*}{$\mathrm{Ni}$} & $1 \times$ & $106.4 \pm 0.3 \mathrm{~b}$ & $109.2 \pm 0.5 \mathrm{~b}$ & $105.3 \pm 0.5 \mathrm{~b}$ & $91.3 \pm 0.0 \mathrm{~b}$ \\
\hline & $10 \times$ & $98.4 \pm 0.8 \mathrm{~b}$ & $107.1 \pm 0.4 \mathrm{~b}$ & $110.0 \pm 0.6 \mathrm{~b}$ & $95.8 \pm 0.0 \mathrm{bc}$ \\
\hline & $100 \times$ & $49.5 \pm 0.8 \mathrm{a}$ & $68.6 \pm 0.5 \mathrm{a}$ & $78.6 \pm 0.1 \mathrm{a}$ & $75.8 \pm 0.0 \mathrm{a}$ \\
\hline \multicolumn{2}{|c|}{ Control } & $100 \mathrm{~b}$ & $100 \mathrm{~b}$ & $100 \mathrm{~b}$ & $100 \mathrm{c}$ \\
\hline \multirow{3}{*}{$\mathrm{Cu}$} & $1 \times$ & $102.6 \pm 0.3 \mathrm{~b}$ & $97.8 \pm 0.8 \mathrm{ab}$ & $119.3 \pm 0.4 \mathrm{~b}$ & $115.8 \pm 0.0 \mathrm{c}$ \\
\hline & $10 \times$ & $108.0 \pm 0.3 \mathrm{~b}$ & $109.2 \pm 0.8 \mathrm{~b}$ & $117.4 \pm 0.6 \mathrm{~b}$ & $103.0 \pm 0.0 \mathrm{~b}$ \\
\hline & $100 \times$ & $89.4 \pm 0.4 \mathrm{a}$ & $93.2 \pm 0.1 \mathrm{a}$ & $105.8 \pm 0.2 \mathrm{a}$ & $91.7 \pm 0.0 \mathrm{a}$ \\
\hline \multicolumn{2}{|c|}{ Control } & $100 \mathrm{~b}$ & $100 \mathrm{ab}$ & $100 \mathrm{a}$ & $100 \mathrm{~b}$ \\
\hline \multirow{3}{*}{$\mathrm{Cd}$} & $1 \times$ & $102.1 \pm 1.8 \mathrm{~b}$ & $96.8 \pm 1.4 \mathrm{c}$ & $101.5 \pm 1.7 \mathrm{c}$ & $102.8 \pm 0.8 \mathrm{c}$ \\
\hline & $10 \times$ & $81.4 \pm 0.8 \mathrm{a}$ & $71.3 \pm 0.9 \mathrm{~b}$ & $69.3 \pm 1.2 \mathrm{~b}$ & $67.1 \pm 1.1 \mathrm{~b}$ \\
\hline & $100 \times$ & $78.9 \pm 3.0 \mathrm{a}$ & $66.7 \pm 1.4 \mathrm{a}$ & $58.9 \pm 0.8 \mathrm{a}$ & $54.6 \pm 0.6 \mathrm{a}$ \\
\hline \multicolumn{2}{|c|}{ Control } & $100 \mathrm{~b}$ & $100 \mathrm{c}$ & $100 \mathrm{c}$ & $100 \mathrm{c}$ \\
\hline \multirow{3}{*}{$\mathrm{Pb}$} & $1 \times$ & $101.5 \pm 0.9 \mathrm{~b}$ & $98.4 \pm 1.4 \mathrm{a}$ & $98.2 \pm 2.0 \mathrm{~b}$ & $97.8 \pm 0.7 \mathrm{c}$ \\
\hline & $10 \times$ & $96.9 \pm 2.0 \mathrm{ab}$ & $91.3 \pm 1.9 \mathrm{a}$ & $82.7 \pm 1.5 \mathrm{a}$ & $70.0 \pm 0.7 \mathrm{a}$ \\
\hline & $100 \times$ & $92.8 \pm 2.0 \mathrm{a}$ & $97.3 \pm 1.2 \mathrm{a}$ & $93.1 \pm 3.0 \mathrm{~b}$ & $85.7 \pm 1.8 \mathrm{~b}$ \\
\hline \multicolumn{2}{|c|}{ Control } & $100 \mathrm{~b}$ & $100 \mathrm{a}$ & $100 \mathrm{~b}$ & $100 \mathrm{c}$ \\
\hline
\end{tabular}

$\mathrm{Con}^{1}$ - concentration; $1 \times$ - the concentration corresponding to the natural content of the metal in the Polish soils; $10 \times$ - the concentration of 10-times higher than the natural content; $100 \times$ - the concentration of 100-times higher than the natural content; means in columns fallowed by different letters within the given metal differ significantly at $\mathrm{P}<0.05$

After 20 days of incubation fungal colonies on the media with ions of those two metals were, respectively, $54.6 \%$ and $75.8 \%$ of the control diameter. In the case of the other heavy metals: lead, copper, and zinc, those values were $85.7 \%, 91.7 \%$, and $100.5 \%$, respectively.

The ions of heavy metals at the concentration of $1 \times$ and $10 \times$ did not influence significantly the growth of Isaria fumosorosea colonies (Table 3). Only cadmium and lead ions reduced the growth by $6.6 \%$ when compared to the control. With respect to cadmium ions this difference was statistically significant. Other ions of heavy metals at both $1 \times$ and $10 \times$ concentrations slightly stimulated the development of I. fumosorosea.

Ions of nickel and zinc added to the medium at the concentration 100 times higher than the natural content in Polish soils limited fungus growth after 20 days the most, by $20.3 \%$ and $15.3 \%$. 
Table 3. The size of colonies of the fungus Isaria fumosorosea on medium in the presence of heavy metals ions (expressed in \% of control)

\begin{tabular}{|c|c|c|c|c|c|}
\hline \multirow{2}{*}{ Metal } & \multirow{2}{*}{$\operatorname{Con}^{1}$} & \multicolumn{4}{|c|}{ Date of observation in days } \\
\hline & & 5 & 10 & 15 & 20 \\
\hline \multirow{3}{*}{$\mathrm{Zn}$} & $1 \times$ & $110.2 \pm 0.9 \mathrm{c}$ & $112.8 \pm 0.4 \mathrm{c}$ & $109.7 \pm 1.0 \mathrm{c}$ & $105.2 \pm 1.8 \mathrm{~b}$ \\
\hline & $10 \times$ & $112.9 \pm 0.0 \mathrm{c}$ & $114.2 \pm 0.7 \mathrm{c}$ & $111.4 \pm 1.5 \mathrm{c}$ & $104.2 \pm 1.1 \mathrm{~b}$ \\
\hline & $100 \times$ & $80.6 \pm 0.0 \mathrm{a}$ & $88.8 \pm 0.3 \mathrm{a}$ & $82.9 \pm 1.8 \mathrm{a}$ & $84.7 \pm 0.5 \mathrm{a}$ \\
\hline \multicolumn{2}{|c|}{ Control } & $100 \mathrm{~b}$ & $100 \mathrm{~b}$ & $100 \mathrm{~b}$ & $100 \mathrm{~b}$ \\
\hline \multirow{3}{*}{$\mathrm{Ni}$} & $1 \times$ & $98.4 \pm 1.2 \mathrm{~b}$ & $105.7 \pm 1.4 \mathrm{~b}$ & $107.3 \pm 1.3 \mathrm{~b}$ & $100.4 \pm 2.5 \mathrm{ab}$ \\
\hline & $10 \times$ & $102.1 \pm 0.0 \mathrm{~b}$ & $102.4 \pm 0.8 \mathrm{~b}$ & $98.3 \pm 2.2 \mathrm{~b}$ & $104.5 \pm 6.3 b$ \\
\hline & $100 \times$ & $69.9 \pm 1.2 \mathrm{a}$ & $73.2 \pm 0.2 \mathrm{a}$ & $76.8 \pm 0.7 \mathrm{a}$ & $79.7 \pm 0.3 \mathrm{a}$ \\
\hline \multicolumn{2}{|c|}{ Control } & $100 \mathrm{~b}$ & $100 \mathrm{~b}$ & $100 \mathrm{~b}$ & $100 \mathrm{ab}$ \\
\hline \multirow{3}{*}{$\mathrm{Cu}$} & $1 \times$ & $103.8 \pm 1.1 \mathrm{a}$ & $110.9 \pm 1.5 \mathrm{a}$ & $109.5 \pm 3.0 \mathrm{a}$ & $103.7 \pm 2.0 \mathrm{~b}$ \\
\hline & $10 \times$ & $106.4 \pm 1.1 \mathrm{a}$ & $110.6 \pm 1.2 \mathrm{a}$ & $107.7 \pm 2.3 \mathrm{a}$ & $101.6 \pm 1.8 \mathrm{~b}$ \\
\hline & $100 \times$ & $101.1 \pm 1.1 \mathrm{a}$ & $99.7 \pm 1.4 \mathrm{a}$ & $98.6 \pm 1.8 \mathrm{a}$ & $90.3 \pm 0.8 \mathrm{a}$ \\
\hline \multicolumn{2}{|c|}{ Control } & $100 \mathrm{a}$ & $100 \mathrm{a}$ & $100 \mathrm{a}$ & $100 \mathrm{~b}$ \\
\hline \multirow{3}{*}{$\mathrm{Cd}$} & $1 \times$ & $92.4 \pm 0.4 \mathrm{a}$ & $92.5 \pm 0.8 \mathrm{a}$ & $93.9 \pm 0.3 \mathrm{a}$ & $93.4 \pm 0.6 \mathrm{a}$ \\
\hline & $10 \times$ & $105.0 \pm 1.2 \mathrm{ab}$ & $103.7 \pm 1.9 \mathrm{~b}$ & $102.7 \pm 1.5 \mathrm{~b}$ & $103.3 \pm 0.5 \mathrm{~b}$ \\
\hline & $100 \times$ & $112.6 \pm 0.5 \mathrm{~b}$ & $107.7 \pm 1.2 \mathrm{~b}$ & $102.8 \pm 0.8 \mathrm{~b}$ & $101.0 \pm 0.2 \mathrm{~b}$ \\
\hline \multicolumn{2}{|c|}{ Control } & $100 \mathrm{ab}$ & $100 \mathrm{ab}$ & $100 \mathrm{ab}$ & $100 \mathrm{~b}$ \\
\hline \multirow{3}{*}{$\mathrm{Pb}$} & $1 \times$ & $89.9 \pm 0.2 \mathrm{a}$ & $88.3 \pm 0.4 \mathrm{~b}$ & $90.4 \pm 0.8 \mathrm{ab}$ & $93.4 \pm 0.4 \mathrm{a}$ \\
\hline & $10 \times$ & $85.8 \pm 0.5 \mathrm{a}$ & $81.5 \pm 0.6 \mathrm{a}$ & $91.9 \pm 1.0 \mathrm{~b}$ & $93.8 \pm 0.3 \mathrm{a}$ \\
\hline & $100 \times$ & $79.8 \pm 0.4 \mathrm{a}$ & $80.3 \pm 0.6 \mathrm{a}$ & $86.2 \pm 0.6 \mathrm{a}$ & $94.7 \pm 0.4 \mathrm{a}$ \\
\hline \multicolumn{2}{|c|}{ Control } & $100 \mathrm{~b}$ & $100 \mathrm{c}$ & $100 \mathrm{c}$ & $100 \mathrm{~b}$ \\
\hline
\end{tabular}

$\mathrm{Con}^{1}$ - concentration; $1 \times-$ the concentration corresponding to the natural content of the metal in the Polish soils; $10 \times$ - the concentration of 10-times higher than the natural content; $100 \times$ - the concentration of 100-times higher than the natural content; means in columns fallowed by different letters within the given metal differ significantly at $\mathrm{P}<0.05$

This difference was statistically significant. It was found that cadmium $100 \times$ concentration did not affect adversely the development of the I. fumosorosea colony, while in the case of lead and copper the colonies were only about $5.9 \%$ and $9.7 \%$ smaller than the control.

Discussing the experiment findings it should be noted that so far there have been no studies on the effects of heavy metal ions on the growth of Isaria tenuipes. This paper, therefore, is the first one in scientific literature devoted to the subject. The experiment showed that 20 days after heavy metal ions were added to the media at the concentration corresponding to their natural content in the Polish soils $(1 \times)$ and 10-times higher $(10 \times)$, they did not significantly inhibit I. tenuipes growth (Table 4). It was found that only in the presence of nickel were the diameters of fungus colonies around $10 \%$ smaller than the control, while in the case of them growing on the medium with cadmium and lead there was even a slight growth stimulation. With the concentration 100 times higher than their natural content in Polish soils, zinc, nickel, and copper ions were the most toxic to I. tenuipes. Within the first 5 days of the experiment the culture with nickel ions had not grown, and within 10 days the I. tenuipes colony had reached only $16.1 \%$ of the control diameter. 20 days after the experiment had started fungal colonies on media 
containing zinc, nickel, and copper at their highest concentration $(100 \times)$ were, respectively, $29.5 \%, 33.8 \%$ and $69.1 \%$ of the size of the control culture.

Table 4. The size of colonies of the fungus Isaria tenuipes on medium in the presence of heavy metals ions (expressed in \% of control)

\begin{tabular}{|c|c|c|c|c|c|}
\hline \multirow{2}{*}{ Metal } & \multirow{2}{*}{$\operatorname{Con}^{1}$} & \multicolumn{4}{|c|}{ Date of observation in days } \\
\hline & & 5 & 10 & 15 & 20 \\
\hline \multirow{3}{*}{$\mathrm{Zn}$} & $1 \times$ & $99.6 \pm 0.9 \mathrm{~b}$ & $99.6 \pm 1.4 \mathrm{~b}$ & $97.8 \pm 1.2 \mathrm{~b}$ & $98.2 \pm 1.8 \mathrm{bc}$ \\
\hline & $10 \times$ & $100.0 \pm 0.9 \mathrm{~b}$ & $95.9 \pm 2.7 \mathrm{~b}$ & $91.5 \pm 2.0 \mathrm{~b}$ & $93.8 \pm 5.6 \mathrm{~b}$ \\
\hline & $100 \times$ & $33.2 \pm 5.6 \mathrm{a}$ & $22.5 \pm 0.8 \mathrm{a}$ & $24.9 \pm 0.7 \mathrm{a}$ & $29.5 \pm 1.1 \mathrm{a}$ \\
\hline \multicolumn{2}{|c|}{ Control } & $100 \mathrm{~b}$ & $100 \mathrm{~b}$ & $100 \mathrm{~b}$ & $100 \mathrm{c}$ \\
\hline \multirow{3}{*}{$\mathrm{Ni}$} & $1 \times$ & $79.9 \pm 5.5 \mathrm{a}$ & $80.9 \pm 4.4 \mathrm{~b}$ & $87.8 \pm 2.2 \mathrm{~b}$ & $90.5 \pm 5.9 \mathrm{~b}$ \\
\hline & $10 \times$ & $69.7 \pm 1.5 \mathrm{a}$ & $74.5 \pm 4.8 \mathrm{~b}$ & $89.8 \pm 0.5 \mathrm{~b}$ & $93.0 \pm 3.1 \mathrm{~b}$ \\
\hline & $100 \times$ & No growth & $16.1 \pm 1.6 \mathrm{a}$ & $24.9 \pm 4.4 \mathrm{a}$ & $33.8 \pm 3.2 \mathrm{a}$ \\
\hline \multicolumn{2}{|c|}{ Control } & $100 \mathrm{~b}$ & $100 \mathrm{c}$ & $100 \mathrm{~b}$ & $100 \mathrm{c}$ \\
\hline \multirow{3}{*}{$\mathrm{Cu}$} & $1 \times$ & $102.4 \pm 0.0 \mathrm{~b}$ & $100.0 \pm 1.2 \mathrm{~b}$ & $97.8 \pm 1.1 \mathrm{~b}$ & $99.4 \pm 2.0 \mathrm{~b}$ \\
\hline & $10 \times$ & $104.5 \pm 1.8 \mathrm{~b}$ & $103.9 \pm 2.3 \mathrm{~b}$ & $101.0 \pm 2.5 \mathrm{~b}$ & $95.3 \pm 8.0 \mathrm{~b}$ \\
\hline & $100 \times$ & $66.8 \pm 3.8 \mathrm{a}$ & $64.7 \pm 2.0 \mathrm{a}$ & $64.7 \pm 0.8 \mathrm{a}$ & $69.1 \pm 1.8 \mathrm{a}$ \\
\hline \multicolumn{2}{|c|}{ Control } & $100 \mathrm{~b}$ & $100 \mathrm{~b}$ & $100 \mathrm{~b}$ & $100 \mathrm{~b}$ \\
\hline \multirow{3}{*}{$\mathrm{Cd}$} & $1 \times$ & $105.2 \pm 2.0 \mathrm{~b}$ & $108.1 \pm 1.2 \mathrm{c}$ & $110.2 \pm 1.0 \mathrm{~b}$ & $105.9 \pm 0.7 \mathrm{~b}$ \\
\hline & $10 \times$ & $96.0 \pm 1.6 \mathrm{a}$ & $97.4 \pm 2.4 \mathrm{ab}$ & $97.6 \pm 0.8 \mathrm{a}$ & $99.1 \pm 0.6 \mathrm{ab}$ \\
\hline & $100 \times$ & $96.0 \pm 1.3 \mathrm{a}$ & $92.9 \pm 1.8 \mathrm{a}$ & $90.8 \pm 0.9 \mathrm{a}$ & $91.3 \pm 1.2 \mathrm{a}$ \\
\hline \multicolumn{2}{|c|}{ Control } & $100 \mathrm{ab}$ & $100 \mathrm{~b}$ & $100 \mathrm{ab}$ & $100 \mathrm{~b}$ \\
\hline \multirow{3}{*}{$\mathrm{Pb}$} & $1 \times$ & $108.0 \pm 0.0 \mathrm{c}$ & $111.6 \pm 0.0 \mathrm{~b}$ & $113.5 \pm 0.6 \mathrm{~b}$ & $106.8 \pm 0.4 b$ \\
\hline & $10 \times$ & $108.0 \pm 0.0 \mathrm{c}$ & $113.2 \pm 1.2 \mathrm{~b}$ & $113.5 \pm 0.5 \mathrm{~b}$ & $107.4 \pm 0.4 \mathrm{~b}$ \\
\hline & $100 \times$ & $86.0 \pm 0.9 \mathrm{a}$ & $98.0 \pm 0.6 \mathrm{a}$ & $104.5 \pm 0.3 \mathrm{a}$ & $106.2 \pm 0.2 \mathrm{~b}$ \\
\hline \multicolumn{2}{|c|}{ Control } & $100 \mathrm{~b}$ & $100 \mathrm{a}$ & $100 \mathrm{a}$ & $100 \mathrm{a}$ \\
\hline
\end{tabular}

$\mathrm{Con}^{1}$ - concentration; $1 \times$ - the concentration corresponding to the natural content of the metal in the Polish soils; $10 \times$ - the concentration of 10-times higher than the natural content; $100 \times$ - the concentration of 100-times higher than the natural content; means in columns fallowed by different letters within the given metal differ significantly at $\mathrm{P}<0.05$

With respect to the fungi I. farinosa and I. fumosorosea this difference was statistically significant. However, after 20 days the presence of cadmium in the medium only to a low degree decreased the size of the I. tenuipes colony, by $8.7 \%$, while lead ions stimulated its growth. It should be noted that out of the entomopathogenic fungi of the Isaria genus, I. tenuipes proved the most sensitive to the presence of zinc, nickel and copper ions used in the concentration 100 times higher than their natural content in Polish soils (Table 5).

\section{Discussion}

Heavy metals are highly toxic to living organisms. They contribute to the deterioration of soil chemical properties and restrict the number of soil microorganisms (Kabata-Pendias and Pendias, 2001; Šmejkalová et al., 2003; Ahmad et al., 2005; Tscherko et al., 2007; Lenart and Wolny-Koładka, 2013). 
Table 5. ANOVA of the data for effect of heavy metal ions on the growth of entomopathogenic fungi from the genus Isaria after 20 days incubation

\begin{tabular}{|c|c|c|c|c|c|c|c|c|c|c|c|}
\hline \multirow{3}{*}{ Source } & \multirow{3}{*}{ df } & \multicolumn{10}{|c|}{ Metals } \\
\hline & & \multicolumn{2}{|c|}{$\mathbf{Z n}$} & \multicolumn{2}{|c|}{$\mathbf{N i}$} & \multicolumn{2}{|c|}{$\mathbf{C u}$} & \multicolumn{2}{|c|}{ Cd } & \multicolumn{2}{|c|}{$\mathbf{P b}$} \\
\hline & & $\mathbf{F}$ & $\mathbf{P}$ & $\mathbf{F}$ & $\mathbf{P}$ & $\mathbf{F}$ & $\mathbf{P}$ & $\mathbf{F}$ & $\mathbf{P}$ & $\mathbf{F}$ & $\mathbf{P}$ \\
\hline $\begin{array}{l}\text { Main effects } \\
\text { I. farinosa } \\
\text { Error }\end{array}$ & $\begin{array}{c}3 \\
12\end{array}$ & 55.7 & 0.00 & 108.1 & 0.00 & 54.2 & 0.00 & 73.6 & 0.00 & 100.4 & 0.00 \\
\hline Total & 15 & & & & & & & & & & \\
\hline $\begin{array}{l}\text { Main effects } \\
\text { I. fumosorosea } \\
\text { Error }\end{array}$ & $\begin{array}{c}3 \\
12\end{array}$ & 38.8 & 0.00 & 5.25 & 0.00 & 7.27 & 0.00 & 12.9 & 0.00 & 11.2 & 0.00 \\
\hline Total & 15 & & & & & & & & & & \\
\hline $\begin{array}{l}\text { Main effects } \\
\text { I. tenuipes } \\
\text { Error }\end{array}$ & $\begin{array}{c}3 \\
12\end{array}$ & 553.1 & 0.00 & 361.7 & 0.00 & 51.8 & 0.00 & 8.39 & 0.00 & 28.4 & 0.00 \\
\hline Total & 15 & & & & & & & & & & \\
\hline
\end{tabular}

Studies performed in vitro suggest certain species of entomopathogenic fungi, and as well as individual strains within species, exhibit different sensitivity to heavy metal ions (Jaworska et al., 1996; Ropek and Para, 2003; Keller et al., 2003; Tkaczuk, 2003, 2005; Gorczyca, 2005; Quesada-Moraga et al., 2007; Pečiulytė and Dirginčiutè-Volodkienė, 2012; Hassn et al., 2014). Some of the metals are inhibitory, while others, such as lead or zinc, can stimulate biomass growth of entomopathogenic fungi at certain levels (Bajan et al., 1998).

Our studies showed the presence of zinc, copper, and cadmium in a medium with concentrations similar to the natural content in Polish soils caused a slight stimulation of I. farinosa colony growth. Those findings were confirmed by the studies of PopowskaNowak et al. (2000), who found that zinc ions added to a medium had stimulating effects in the initial phase of I. farinosa fungus growth. By examining various species of entomopathogenic fungi in the soil of Sweden Arnebrandt et al. (1987) and Nordgren et al. (1985) observed that two species: I. farinosa and B. bassiana, had the greatest tolerance to soil contaminated with copper and zinc. El-Sharouny et al. (1988) found in their study that Isaria and Metarhizium Sorokin were resistant to high content of zinc in the soils of Egypt. Hassn et al. (2014) studied the effect of metal ions on the growth of Isaria javanica (Bally) Samson and Hywel-Jones (= Paecilomyces javanicus) found that zinc, copper, and cadmium in amounts corresponding to their natural content in soils, as well as cadmium in concentration 10 times higher than the natural content, did not affect colony growth of this fungus significantly. Other species of entomopathogenic fungi have been shown to be tolerant and resistant to high contaminations of the soils, by heavy metals (Arnebrandt et al., 1987; Fomina et al., 2007). Trevors et al. (1986), Gaad (1993), and Zimmermann and Wolf (2002) found that entomopathogenic fungi display relatively high resistance to heavy metals, or produce mutations capable of tolerating high concentration. Additionally, Popowska-Nowak et al. (2004) observed that entomopathogenic fungi can employ adaptive mechanisms in areas heavily contaminated by heavy metals. Pečiulytė and Dirginčiutė-Volodkienè (2012) also 
observed higher concentration of copper ions added to a medium stimulates the number of infectious units produced by Peacilomyces inflatus (Burnside) J.W. Carmich. They also found by extending the breeding time, tolerance to copper and zinc increased, with some species starting growth on the first day of the experiment, and others as late as after 57 days. Fungus species belonging to Beauveria, Isaria or Metarhizium genus are among entomopathogenic fungi with the highest tolerance to high concentrations of heavy metals in soils, having an ability to accumulate them (Kameo et al., 2000; Fomina et al., 2007; Tkaczuk, 2008). Gorczyca (2005) reported selected metal ions, including cadmium, lead, copper, manganese, magnesium, and zinc stimulated fungal biomass growth of B. bassiana (Bals.) Vuill. strain Bb5.

Heavy metals in high concentrations, can significantly limit growth, spore germination, and pathogenicity of fungi for in vitro studies. Lead has a great capacity to accumulate in the environment can be particularly toxic to fungus cells (Ropek and Para, 2003; Jaworska and Gorczyca, 2004; Tkaczuk, 2005; Hassn et al., 2014). Ropek and Para (2003) observed that the heavy metals they used restricted the growth of Paecilomyces farinosus (= Isaria farinosa) significantly, and the ions of lead, cadmium, zinc, and copper had the most toxic effects on this fungus isolate.

In our studies concentrations of cadmium and lead at levels 10 times higher than the natural content in Polish soils showed an inhibitory influence on the growth of the $I$. farinosa. Levels of cadmium and nickel at 100 times higher than the natural soil content greatly reduced fungal growth. Tkaczuk (2005) showed nickel had the greatest inhibitory effects on the germination of spores of Pandora neoaphidis (Remaud and Hennebert). Hassn et al. (2014) reported that cadmium, copper, and zinc ions at the concentration 100 times higher than the natural content in the soils of Iraq, regardless of the period of observation, completely inhibited the growth of an I. javanica. Tkaczuk (2008) reported that cadmium was only slightly toxic to entomopathogenic fungi $B$. bassiana and $M$. anisopliae tested in vitro studies, but significantly reduced the number of colony forming units (CFU) of these fungi in soil. Jaworska and Gorczyca (2004) observed that only very high soil contamination with heavy metals $(321 \mathrm{mg} \mathrm{Cd}, 1294$ $\mathrm{mg} \mathrm{Cu}, 1974 \mathrm{mg} \mathrm{Pb}$ and $3427 \mathrm{mg} \mathrm{Zn} \times \mathrm{kg}^{-1}$ ) caused a decrease in I. farinosa, $B$. bassiana and $M$. anisopliae pathogenicity to Galleria mellonella larvae.

Heavy metal ions added to the medium at the concentration corresponding to the natural content in Polish soils and 10 times higher did not affect significantly the growth of I. fumosorosea. The relatively high resistance of $I$. fumosorosea to the effects of some heavy metals is confirmed by research of Gorczyca and Ropek (2000), Tkaczuk (2003, 2008), and Pečiulytė and Dirginčiutė-Volodkienè (2012).

We have shown that cadmium and lead in the highest concentration caused only a small reduction in the growth of the I. fumosorosea. Our results that indicated growth of the I. fumosorosea was inhibited by high levels of nickel and zinc were similar to studies of Jaworska et al. (1996) and Tkaczuk (2003). It is worth noting that in our studies cadmium ions showed no significant inhibitory effect on the growth of this fungus. Our results were confirmed by Tkaczuk (2008), who concluded that cadmium used for in vitro studies showed low toxicity to Isaria fungi. However, Gorczyca and Ropek (2000) reported that adding cadmium to a medium not only limited the growth of $P$. fumosoroseus (=I. fumosorosea), but also reduced the amount of its biomass. They further reported that zinc and copper has limited negative effects. Gorczyca and Ropek (2000) reported the accumulation of metal ions was up to 3 to 5 times higher in $P$. fumosoroseus biomass than in the culture medium. 
Heavy metals affect growth, morphology or metabolism of soil organisms (Niklińska and Chmiel, 1997). Pečiulytė and Dirginčiutė-Volodkienè (2012) reported fungi with the greatest resistance to heavy metals do not accumulate them in their biomass but bind them to the surface of their cells. It is known that fungi can accumulate significant amounts of metals. The cell walls of fungi are composed of polysaccharides, proteins and lipids which contain functional groups with potential metal complexing capacities (Trevors et al., 1986; Gaad, 1993).

Metals in soil are present as free metal ions, soluble metal complexes, exchangeable metal ions, organically bound metals, precipitated or insoluble compounds such as oxides, carbonates and hydroxides (Leyval et al., 1997). The mobility of metals in soil is dependent of their speciation, which is controlled by hydrochemical variables $(\mathrm{pH}$, redox potential, presence of complexing inorganic and organic an-ions, ionic strength) as well as by their interactions with solid surface. The toxicity of metals in soil depends on their bioavailability, which, according to Berthelin et al. (1995), is a function not only of their total concentration but also of physico-chemical and biological (e.g. biosorption, bio-accumulation and solubilization) factors. The negative effects of heavy metals on entomopathogenic fungi on metabolism, growth, germination and differentiation may vary, depending on the fungal species, metal concentration, and other physico-chemical factors such as soil organic matter and clay content (Gaad, 1993; Tobin et al., 1994).

\section{Conclusions}

Heavy metal ions added to fungal culture medium in concentrations corresponding to the natural content found in soils of Poland did not significantly affect the growth of cultures of Isaria ssp. When compared to control cultures, slight increases were noted. At a concentrations 10 times higher than the natural content in Polish soils, heavy metal ions had little influence on the growth of the Isaria fungal colonies. Cadmium and nickel has the highest inhibitory effects Isaria. Heavy metal concentrations of 100 times greater than levels found naturally had the greatest toxic effects. Nickle was the most toxic and lead was the least toxic. Isaria tenuipes showed the greatest sensitivity to heavy metals I. fumosorosea having the highest tolerance. Strong pollution of soil by some heavy metals could be a restrictive factor of development of entomopathogenic fungi in the environment. Further studies on heavy metal resistance of different isolates within the particular genus of these fungi can be performed to search of virulent strains to be applied as biopesticides.

Acknowledgements. The results of the research carried out under the research theme No. 360/13/S were financed from the science grant granted by the Ministry of Science and Higher Education.

\section{REFERENCES}

[1] Ahmad, I., Hayat, S., Ahmad, A., Inam, A., Samiullah, I. (2005): Effect of heavy metal on survival of certain groups of indigenous soil microbial population. - Journal of Applied Sciences and Environmental Management 9: 115-121.

[2] Arnebrandt, K., Baath, E., Nordgren, A. (1987): Copper tolerance of microfungi isolated from polluted and unpolluted forest soil. - Mycologia 79(6): 890-895. 
[3] Badura, L., Piotrowska-Seget, Z. (2000): Heavy metals in the environment and their impact on soil microorganisms. - Ecological Chemistry and Engineering 7(11): 11351142.

[4] Bajan, C., Tyrawska, D., Popowska-Nowak, E., Bieńkowski, P. (1998): Biological response of Beauveria bassiana strains to heavy metal pollution and their accumulative ability. - Ecological Chemistry and Engineering 5(8-9): 685-692 (in Polish).

[5] Baldrian, P. (2003): Interaction of heavy metals with white-rot fungi. - Enzyme and Microbial Technology 32: 78-91.

[6] Batta, Y. A., Rahman, M., Powis, K., Baker, G., Schmidt, O. (2011): Formulation and application of the entomopathogenic fungus: Zoophthora radicans (Brefeld) Batko (Zygomycetes:Entomophthorales). - Journal of Applied Microbiology 110: 831-839.

[7] Berthelin, J., Munier-Lamy, C., Leyval, C. (1995): Effect of Microorganisms on Mobility of Heavy Metals in Soils. - In: Huang, P. M., Berthelin, J., Bollag, J. M., McGill, W. B., Page, A. L. (eds.) Environmental Impacts of Soil Component Interactions: Metals, Other Inorganics, and Microbial Activities. CRC, Boca Raton, FL.

[8] Chandler, D., Hay, D., Reid, A. P. (1997): Sampling and occurrence of entomopathogenic fungi and nematodes in UK soils. - Applied Soil Ecology 5: 133-141.

[9] Chandler, D., Davidson, G., Pell, J. K., Ball, B. V., Shaw, K., Sunderland, K. D. (2000): Fungal biocontrol of Acari. - Biocontrol Science and Technology 10: 357-384.

[10] El-Sharouny, H. M. M., Bagy, M. M., El-Shanawany, A. A. (1988): Toxicity of heavy metals to Egyptian soil fungi. - International Biodeterioration 24: 65-68.

[11] Ferron, P. (1981): Pest Control by the Fungi Beauveria and Metarhizium. - In: Burges, H. D. (ed.) Microbial Control of Pest and Plant Diseases 1970-1980. Academic Press, London.

[12] Fomina, M., Charnock, J. M., Bowen, A., Gadd, G. M. (2007): X-ray absorption spectroscopy (XAS) of toxic metal mineral transformations by fungi. - Environmental Microbiology 9(2): 308-321.

[13] Fukatsu, T., Sato, H., Kuriyama, H. (1997): Isolation, inoculation to insect host, and molecular phylogeny of an entomogenous fungus Paecilomyces tenuipes. - Journal of Invertebrate Pathology 70: 203-208.

[14] Gaad, G. M. (1993): Interaction of fungi with toxic metals. - New Phytologist 124: 2560.

[15] Gonzalez, F., Tkaczuk, C., Dinu, M. M., Fiedler, Ż., Vidal, S., Zchori-Fein, E., Messelink, G. J. (2016): New opportunities for the integration of microorganisms into biological pest control systems in greenhouse crops. - Journal of Pest Science 89(2): 295311.

[16] Goyer, R. A. (2001) Toxic Effects of Metals. - In: Klaassen, C. D. (ed.) Cassarett and Doull's Toxicology: The Basic Science of Poisons. McGraw-Hill, New York.

[17] Gorczyca, A. (2005): Effect of metal ions on selected characteristics of Beauveria bassiana (Bals) Vuil. Strain Bb5. Part II. Patogenicity. - Ecological Chemistry and Engineering 12(4): 401-404.

[18] Gorczyca, A., Ropek, D. (2000): Accumulation of some metal ions on biomass of insect pathogenic fungus Paecilomyces fumosoroseus. - IOBC/WPRS Bulletin 23(2): 211-216.

[19] Hajek, A. E. (1997): Ecology of terrestrial fungal entomopathogens. - Advances in Microbial Ecology 15: 193-249.

[20] Hajek, A. E., Leger, R. J. (1994): Interaction between fungal pathogens and insect hosts. - Annual Review of Entomology 39: 293-322.

[21] Hassn, W. A., Asaf, L. H., Salih, M. S. M. (2014): Effect of heavy metals ions on growth, sporulation and pathogenicity of Isaria javanica = (Paecilomyces javanicus). International Journal of Pure and Applied Sciences and Technology 20(2): 1-7.

[22] Humber, A. R. (2012): Identification of Entomopathogenic Fungi. Chapter VI. - In: Lacey, L. A. (ed.) Manual of Techniques in Invertebrate Pathology. Academic Press, London. 
[23] Inglis, G. D., Enkerli, J., Goettel, M. S. (2012): Laboratory Techniques Used for Entomopathogenic Fungi: Hypocreales. Chapter VII. - In: Lacey, L. A. (ed.) Manual of Techniques in Invertebrate Pathology. Academic Press, London.

[24] Jaworska, M., Gorczyca, A. (2004): Effect of metal ions on entomopathogenic fungi pathogenicity. - Ecological Chemistry and Engineering 11(4-5): 327-339.

[25] Jaworska, M., Radkowska, A., Ropek, D., Tomasik, P. (1996): Effect of metals ions on Paecilomyces fumosoroseus. - IOBC/WPRS Bulletin 19(9): 221-224.

[26] Kabata-Pendias, A., Pendias, H. (1999): Biogeochemistry of Trace Elements. - PWN, Warszawa (in Polish).

[27] Kabata-Pendias, A., Pendias, H. (2001): Trace Elements in Soils and Plants. - CRC Press, Boca Raton, London.

[28] Kameo, S., Iwahashi, H., Kojima, Y., Satoh, H. (2000): Induction of metallothioneins in the heavy metal resistant fungus Beauveria bassiana exposed to copper or cadmium. Analysis 28(5): 382-385.

[29] Keller, S., Zimmermann, G. (1989): Mycopathogens of Soil Insects. - In: Wilding, N., Collins, N. M., Hammond, P. M., Webber, J. F. (eds.) Insect-Fungus Interactions. Academic Press, London.

[30] Keller, S., Kessler, P., Schweizer, C. (2003): Distribution of insect pathogenic soil fungi in Switzerland with special reference to Beauveria bassiana and Metarhizium anisopliae. - BioControl 48: 307-319.

[31] Lenart, A., Wolny-Koładka, K. (2013): The effect of heavy metal concentration and soil $\mathrm{pH}$ on the abundance of selected microbial groups within arcelormittal Poland steelworks in Cracow. - Bulletin of Environmental Contamination and Toxicology 90(1): 85-90.

[32] Leyval, C., Turnau, K., Haselwandter, K. (1997): Effect of heavy metal pollution on mycorrhizal colonization and function: physiological, ecological and applied aspects. Mycorrhiza 7: 139-153.

[33] Meyling, N. V., Eilenberg, J. (2007): Ecology of the entomopathogenic fungi Beauveria bassiana and Metarhizium anisopliae in temperate agroecosystems: Potential for conservation biological control. - Biological Control 43: 145-155.

[34] Micó, C., Peris, M., Sánchez, J., Recatalá, L. (2006): Heavy metal content of agricultural soils in a Mediterranean semiarid area: the Segura River Valley (Alicante, Spain). Spanish Journal of Agricultural Research 4(4): 363-372.

[35] Niklińska, M., Chmiel, M. (1997): Comparison of Resistance to Heavy Metals of Soil Microorganisms of Regions Heavily Contaminated with Copper or Zinc. - In: Barabasz, W. (ed.) Microorganisms in the Environment. Entry Activity and Meaning. Katedra MikrobiologiiWydział Rolniczy Akademia Rolnicza im. Hugo Kołłątaja w Krakowie, Kraków, pp. 491-503 (in Polish).

[36] Nordgren, A., Bääth, E., Söderström, B. (1985): Soli microfungi in an area polluted by heavy metals. - Canadian Journal of Botany 63: 448-455.

[37] On, Z. L., Yang, X. E., Stoffella, P. J. (2005): Trace elements in agroecosystems and impacts on the environment. - Journal of Trace Elements in Medicine and Biology 19(23): $125-140$.

[38] Pečiulytė, D., Dirginčiutė-Volodkienè, V. (2012): Effect of zinc and copper on cultivable populations of soil fungi with special reference to entomopathogenic fungi. - Ekologija 58(2): 65-85.

[39] Popowska-Nowak, E., Bieńkowski, P., Bajan, C., Tyrawska, D. (2000): Influence of some heavy metal ions on biological activity of two strains of entomopathogenic fungus Paecilomyces farinosus. - Ecological Chemistry and Engineering 7(11): 1221-1228.

[40] Popowska-Nowak, B., Sosak-Świderska, C., Bajan, C., Bieńkowska, P. (2004): Response of isolates of entomopathogenic fungus Metarhizium anisopliae to heavy metal pollution and their accumulative abilities. - Ecological Chemistry and Engineering 11(1): 71-77.

[41] Quesada-Moraga, E., Navas-Cortés, J. A., Maranhao, E. A. A., Ortiz-Urquiza, A., Santiago-Àlvarez, C. (2007): Factors affecting the occurrence and distribution of 
entomopathogenic fungi in natural and cultivated soils. - Mycological Research 111: 947-966.

[42] Ropek, D., Para, A. (2003): The effect of heavy metal ions and their complexions upon growth, sporulation and pathogenicity of the entomopathogenic fungus Paecilomyces farinosus. - Polish Journal of Environmental Studies 12(2): 227-230.

[43] Ropek, D., Krysa, A., Rola, A., Frączek, K. (2014): Antagonistic effect of Trichoderma viride on entomophatogenic fungi Beauveria bassiana, Isaria fumosorosea and Metarhizium anisopliae in vitro. - Polish Journal of Agronomy 16: 57-63 (in Polish).

[44] Schemmer, R., Chládekowá, P., Medo, J., Barta, M. (2016): Natural prevalence of entomopathogenic fungi in hibernating pupae of Cameraria ohridella (Lepidoptera: Gracillariidae) and virulence of selected isolates. - Plant Protection Science 52(3): 199208.

[45] Sheeba, G., Seshardi, S., Raja, N., Janarthana, S., Ignacinutha, S. (2001): Efficacy of Beauveria bassiana for control of the rice weevil Sitophilu oryzae L (Coleoptera: Curculionidae). - Applied Entomology and Zoology 36: 117-120.

[46] Showket, A. D., Bashir, A. R, Kandoo, A. A. (2017): Insect pest management by entomopathogenic fungi. - Journal of Entomology and Zoology 5(3): 1185-1190.

[47] Singh, J., Kalamdhad, A. S. (2011): Effects of heavy metals on soil, plants, human health and aquatic life. - International Journal of Research in Chemistry and Environment 1(2): $15-21$.

[48] Šmejkalová, M., Mikanová, O., Borůvka, L. (2003): Effects of heavy metal concentrations on biological activity of soil micro-organisms. - Plant, Soil and Environment 49: 321-326.

[49] Tkaczuk, C. (2003): Effect of selected metal ions on the growth and germination of entomopathogenic fungus Paecilomyces fumosoroseus (Wize) Brown and Smith. Ecological Chemistry and Engineering 10(3-4): 323-328.

[50] Tkaczuk, C. (2005): The effect of selected metal ions on the growth and conidial germination of the aphid pathogenic fungus Pandora neopahidis (Remaudiere at Hennebert). - Polish Journal of Environmental Studies 14(6): 897-902.

[51] Tkaczuk, C. (2008): Occurrence and infective potential of entomopathigenic fungi in soils of agrocenoses and seminatural habitats in the agricultural landscape. - Scientific Dissertation No. 94. Publisher AP, Siedlce (in Polish).

[52] Tobin, J. M., White, C., Gadd, G. M. (1994): Metal accumulation by fungi: Applications in environmental biotechnology. - Journal of Industrial Microbiology 13: 126-130.

[53] Tomalak, M. (2010): Market for biological control agents and their legal regulation. Progress in Plant Protection 50(3): 1053-1063 (in Polish).

[54] Trevors, J. T., Stratton, G. W., Gaad, G. M. (1986): Cadmium transport, resistance and toxicity in algae, bacteria and fungi. - Canadian Journal of Microbiology 32: 447-456.

[55] Tscherko, D., Kandeler, E., Bárdossy, A. (2007): Fuzzy classification of microbial biomass and enzyme activity in grassland soils. - Soil Biology and Biochemistry 39: 1799-1808.

[56] Vänninen, I. (1996): Distribution and occurrence of four entomopathogenic fungi in Finland. Effect of geographical location, habitat type and soil type. - Mycological Research 100: 93-101.

[57] Zimmermann, M., Wolf, K. (2002): A Comprehensive Treatise on Fungi as Experimental Systems for Basic and Applied Research. Bisorption of Metal. - In: Osiewicz, N. D. (ed.) Industrial Applications. Springer-Verlag, Berlin Heidelberg.

[58] Zimmermann, G. (2008): The entomopathogenic fungi Isaria farinosa (formerly Paecilomyces farinosus) and the Isaria fumosorosea species complex (formerly Paecilomyces fumosoroseus): biology, ecology and use in biological control. - Biocontrol Science and Technology 18: 865-901. 